\title{
Improving Student Ability in Poem Appreciation Through Inquiry-Based Learning Model
}

\author{
$1^{\text {st }}$ Sukini \\ Indonesian Language and Art Education Department \\ Faculty of Teaching and Education \\ University of Widya Dharma \\ Klaten, Indonesia \\ sukinibima@gmail.com \\ $3^{\text {rd }}$ Muhammad Rohmadi \\ Indonesian Department \\ Faculty of Teaching and Education \\ Sebelas Maret University Surakarta, Indonesia \\ rohmadi_dbe@yahoo.com
}

\author{
$2^{\text {nd }}$ Andayani \\ Indonesian Department, \\ Faculty of Teaching and Education \\ Sebelas Maret University \\ Surakarta, Indonesia \\ bu anda09@yahoo.co.id3 \\ $4^{\text {th }}$ Budhi Setiawan \\ Indonesian Department \\ Faculty of Teaching and Education, \\ Sebelas Maret University Surakarta, Indonesia \\ buset.74@gmail.com
}

\begin{abstract}
The ability of university students from Indonesian Language and Art Education Department in Poem Appreciation has not been optimum yet. The teaching and learning process was lecturer-centered that did not involve the students actively inside. Consequently, many of them were bored and paid less attention to the lecturer's explanation. For this reason, an inquiry-based learning model is proposed as it belongs to an innovative learning model which is student-centered and can activate students in the learning process. This research was classroom Action Research conducted in two cycles. Each cycle consists of planning, acting, observing, and reflecting. The research result showed that an inquiry-based learning model could improve the ability of students in Poem Appreciation. Besides, the observation results also indicated that by inquiry learning model, the students became more active and autonomous in learning. (Abstract)
\end{abstract}

Keywords-inquiry-based learning, Poem Appreciation (key words)

\section{INTRODUCTION}

The teaching of poem at the Department of Indonesian Language and Art Education is delivered by the course of Poem Appreciation and Creative Writing. This research was focused on the teaching of Poem Appreciation to the fourth semester students in the academic year 2015/2016 at the Department of Indonesian Language and Art of Widya Dharma University in Klaten. So far, the teaching of Poem Appreciation has been lecturer-centered in which most of lecturers explain the teaching materials directly through expository method. Consequently, the students became inactive and less passionate to the learning process. Students were not involved actively in the learning activity (Sukini, et.al. 2016).
This kind of learning has not optimized the student's ability in appreciating poem yet. Besides, it has not met the government requirement stated in the Minister Regulation of Research and Technology for Higher Education No. 44 in 2015 article 11 verse 1 regarding student-centered learning as the characteristics of learning process in every study program yet. Therefore, the teaching of Poem Appreciation must apply student-centered innovative learning by inquiry learning model.

Inquiry-based learning (heuristic) refers to a series of learning activity emphasizing on the process of thinking critically and analytically to seek and find out answers of problems questioned (Sanjaya, 2006:196). This learning model assumes that human has his own encouragement to find his knowledge since he was born. Curiosity about natural condition belongs to human destiny since his birth. Human wants to recognize everything through the senses of tasting, listening, looking, etc. since his childhood. Even until someone is adult, his curiosity together with brain and mind will keep developing. Knowledge of human will be meaningful if it is based on his curiosity. For this reason, inquiry learning is developed.

Inquiry-based learning places students as active and autonomous learners who are responsible for their learning. Learning materials are not given directly through expository method but they are sought and found by students during their learning process. Thus, inquiry-based learning requires selfregulating competence. This characteristic is in line with psychological condition of students who want to get more knowledge in challenging situation (Harsono and Dwiyanto, 2005:2). By inquiry learning model, students become active in learning as they are 
demanded to seek and find their knowledge to reach the learning objectives.

Inquiry learning has three types of learning activities as follows: (1) rational activity, (2) experimental activity, and (3) discovery activity. Rational activity is initiated by making generalization through giving questions and reinforcement. In the experimental activity, learners test the validity of certain hypotheses, while in the discovery activity, learners explore a concept directly through three phases i.e. learning cycle, guided inquiry, and pure inquiry (Barman and Kotar,1989:2-3).

In the second phase of guided inquiry, learners are guided to have exploration through some phases as follows: (1) lecturer proposes questions to be explored and gives materials, (2) students are given opportunity to do exploration, (3) students test the hypotheses and draw temporary conclusion, (4) lecturer helps students making conclusion based on group consensus. In the last phase of pure inquiry, students are given freedom to explore. This phase is carried out sequentially as follows: (1) lecturer gives materials to do exploration, (2) lecturer gives clues related to supporting equipment that will be used and to the procedures of occupational safety (particularly for learning activity which uses laboratory), (3) students explore based on their own competences. Type of activity implemented in this research is a discovery inquiry-based learning model with four cycles of Tompkins model (2001)i.e. problem statement, data collection, analysis, and conclusions.

The ability in poem appreciation wanted to improve in this research is the achievement of the fourth Basic Competence i.e. understanding, identifying, finding, and explaining the physical structures of poem (diction, language style, image, versification, and typography). By an inquiry-based learning model, the students' abilities in Poem Appreciation as well as their liveliness in learning can be improved.

\section{RESEARCH METHODOLOGY}

This research belongs to Classroom Action Research conducted in two cycles. Each cycle consists of four phases as follows: (1) planning, (2) acting, (3) observation, and (4) reflecting. The research subjects were 40 students of Indonesian Language and Art Education Department at Widya Dharma Klaten University in the fourth semester of academic year 2015/2016. All of them took the course of Poem Appreciation. The data sources comprised primary and secondary data. The former data were the results of Poem Appreciation test and interview between lecturer and students, while the later ones were syllabus, students' attendance, observation to students and lecturer, and student's questionnaire result.

The data were collected through test, observation, interview, and questionnaire. Triangulation of source and technique were used as data validity. The data were then processed by (1) data completeness checking, (2) data tabulation, and (3) data analysis.

Comparative-descriptive technique (comparativedescriptive statistics) and critical analysis technique were employed to analyze the data. The first technique was used for quantitative data by comparing the students' results of Poem Appreciation in each cycle. Meanwhile, the last technique was employed for qualitative data by exploring the strengths and weaknesses of the performances of students and lecturer after the teaching-learning process. The results both analyses became the basis for formulating the plan for the next action in the following cycle. The data were analyzed together with or after the data collection.

The research procedure consists of four phases i.e. planning, acting, observing, and reflecting. The planning phase began with arranging Lesson Plan of the course and preparing learning material, learning media, observation sheet, assignment, and evaluation. The action phase included the implementation of the Lesson Plan. The observing phase was carried out by observing the activities of students and lecturer during the teaching and learning process. The reflecting phase was done by analyzing and evaluating the results.

\section{FINDING AND DISCUSSION}

The research results of both cycles showed that there was great improvement as there was improvement on the lowest, highest, and average scores as well as the classical completion. The detail of improvement can be seen in Table 1 .

Table 1. Recapitulation on Achievement Scores

\begin{tabular}{|c|c|c|c|}
\hline Notes & Pre-cydt & Cydele I & Gydell \\
\hline The lowest scones & 54 & 60 & 65 \\
\hline The highsst scours & 75 & 86 & 90 \\
\hline Avernge scones & 6025 & $64 . ?$ & 76.9 \\
\hline Clessical Completion & $17.5 \mathrm{k}$ & $525 \%$ & $925 \%$ \\
\hline
\end{tabular}

In pre-cycle, the student's ability in Poem Appreciation was low shown by the lowest score 54, the highest score 75 , and average score 60.25 with classical completion $17.5 \%$. Only 7 out of 40 students could pass 70 as the Minimum Completion Criteria. The 33 remaining students or $82.5 \%$ could not reach 70. Therefore, an effort to improve the ability to appreciate poem is required, exactly by implementing inquiry learning model.

The research on improving student's ability in Poem Appreciation by inquiry-based learning model was carried out in two cycles. The first cycle was on Wednesday, 30 March 2016 at 07.30-09.10, while the second meeting was on Wednesday, 6 April 2016 at 
07.30-09.10 WIB. Table 1 showed that the ability of students in Poem Appreciation improved from initial condition/pre-cycle to Cycle I. The lowest score of pre-cycle by 54 increased to 60 (improved by $15 \%$ ). The highest score in Cycle I also got better from 75 to 86 (increased by $27.5 \%$ from pre-cycle). The average score increased from 60.25 to 71.4 (increased by $27.9 \%$ ). The classical completion improved from $17.5 \%$ to $52.5 \%$ (improved by $35 \%$ ). Table 2 demonstrates the distribution of data frequency on the student's ability in appreciating the physical structure of poem n cycle I.

Table 2.Distribution of Data Frequency on the Score of Poem Appreciation Ability in Cycle I

\begin{tabular}{|c|c|c|c|c|c|c|}
\hline No. & $\begin{array}{c}\text { Soure } \\
\text { Interval }\end{array}$ & $\begin{array}{l}\text { Frequency } \\
\text { (fi) }\end{array}$ & Median (ii) & Total fi.xi & $\begin{array}{c}\text { Percentage } \\
\text { (\%) }\end{array}$ & Notes \\
\hline 1. & $60-64$ & 6 & 62 & 124 & 15 & Failat \\
\hline 2 & $65-69$ & 13 & $6 ?$ & 871 & 325 & Failod \\
\hline 3 & $70-74$ & 12 & 72 & 894 & 30 & Passed \\
\hline 4 & $75-19$ & 4 & $7 ?$ & $\mathrm{X} 8$ & 10 & Passod \\
\hline 5 & (9) -84 & 3 & 82 & 246 & 75 & Passed \\
\hline 6 & $85-89$ & 2 & 87 & 174 & 5 & Pasost \\
\hline Tots & & 40 & & 2587 & {$[00$} & \\
\hline \multicolumn{7}{|c|}{ Averge sore $=2887 ; 40-64$ ? } \\
\hline \multicolumn{7}{|c|}{ Clascial Complotion $=(21-49) \times 10 K R_{0}=52.5 \%$} \\
\hline \multicolumn{7}{|c|}{ Below Menimum Campletion Crierna $=(19.40) \times 100 \% 6=47.5 \%$} \\
\hline \multicolumn{7}{|c|}{ Highest soore - 86} \\
\hline \multicolumn{7}{|c|}{ Lomest solec $=60$} \\
\hline
\end{tabular}

The level of classical completion in Poem Appreciation based on the physical structure of poem in Cycle I obtained $52.5 \%$ with the average score 64.7. There were 21 students gaining the score above the Minimum Completion Criteria. Since those numbers were still below the Minimum Completion Criteria, Cycle II was required. Based on the result of reflection in Cycle I, the plan of inquiry-based learning for Cycle II was proposed. It was still in the same Basic Competence i.e. understanding, identifying, finding, and explaining the physical structure of poem. It was carried out on Wednesday, April 13, 2016 at $08.30-09.10$ a.m. the results of Cycle II are presented at Table 3.

Table 3.Distribution of Data Frequency on Student's Score in Poem Appreciation in Cycle II

\begin{tabular}{|c|c|c|c|c|c|c|}
\hline So. & $\begin{array}{c}\text { Scurt } \\
\text { Interval }\end{array}$ & $\begin{array}{l}\text { Frequetacy } \\
\text { (fi) }\end{array}$ & Median (xi) & Fivi & $\begin{array}{c}\text { Percentage } \\
\text { (\%) }\end{array}$ & Notes \\
\hline I. & $65-69$ & 3 & 67 & 201 & 7.5 & Failed \\
\hline 2 & $76-74$ & 11 & $\pi 2$ & 992 & 27.5 & Passed \\
\hline 3. & $75-79$ & 18 & 77 & 1386 & 45 & Passed \\
\hline 4 & $80-84$ & 1 & 82 & 82 & 2.5 & Passed \\
\hline 5. & $85-89$ & 6 & 87 & 522 & 15 & Passed \\
\hline 6 & $90-94$ & $T$ & 92 & 92 & 2.5 & Passed \\
\hline & Total & 40 & & 3.075 & 100 & \\
\hline \multicolumn{7}{|c|}{ Average scuce $-3.075: 40-76.9$} \\
\hline \multicolumn{7}{|c|}{ 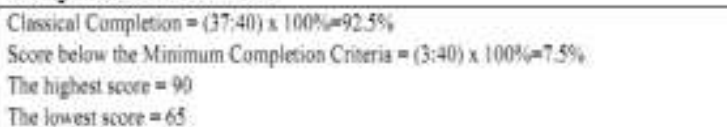 } \\
\hline
\end{tabular}

In Poem Appreciation in Cycle II was $92.5 \%$ with the average score 76.9 . There were 37 out of 40 students $(92.5 \%)$ passed the Minimum Completion Criteria. The remaining 3 students (7.5\%) were below the Minimum Completion Criteria. From Cycle I to Cycle II, the improvement occurred on the level of classical completion by $40 \%$, average score by $11.13 \%$ (from 71.4 to 74.85 , the lowest score by 5 points (from 60 to 65 ), the highest score by 4 points (from 86to 90).

From the initial condition or pre-cycle to Cycle II, the student's ability in Poem Appreciation improved by $75 \%$ for classical completion (from $17.5 \%$ to 92.5\%), 16.65 for average score (from 60.25 to 76.9 ), $27.5 \%$ for the lowest score (from 54 to 65 ), $37.5 \%$ for the highest score (from 75 to 90). These results led to the conclusion that inquiry-based learning model could improve student's ability in Poem Appreciation.

Table 4 showed the results of observation on the teaching and learning process in pre-cycle, cycle I, and Cycle II. It demonstrated the percentages of student's liveliness and autonomy in learning.

TABle 4.Percentages on STUdent's LiVeliness AND LEARNING AUTONOMY

\begin{tabular}{|c|c|c|c|c|}
\hline Observed Aspeets & Period & Categon & $\begin{array}{c}\text { Total } \\
\text { Stedents }\end{array}$ & Perectatage \\
\hline \multirow[t]{9}{*}{ Lweliness } & Pré-cyde & Bad & 21 & $52.5 \%$ \\
\hline & & \begin{tabular}{|l|} 
Moderale \\
\end{tabular} & 10 & $25 \%$ \\
\hline & & Good & 9 & $22.5 \%$ \\
\hline & Cycle! & Bal & 10 & $25 \%$ \\
\hline & & \begin{tabular}{|l} 
Moderate \\
\end{tabular} & 15 & $37.5 \%$ \\
\hline & & Good & 15 & $37,5 \mathrm{v}$ \\
\hline & Cyclefli & Gad & 5 & $12.5 \%$ \\
\hline & & \begin{tabular}{|l|} 
Soderale. \\
\end{tabular} & 17 & 42.54 \\
\hline & & Good & 18 & $45 \%$ \\
\hline \multirow[t]{9}{*}{$\begin{array}{l}\text { Learning } \\
\text { Auteaeary }\end{array}$} & Pre-cycie & Bud & 16 & $40 \%$ \\
\hline & & Moderate & 17 & $42.5 \%$ \\
\hline & & Good & 7 & $17,5 \%$ \\
\hline & Cycle I & Bad & 8 & $20 \%$ \\
\hline & & Moderati & 21 & $52.5 \%$ \\
\hline & & Good & 11 & $27.5 \%$ \\
\hline & Cycle II & Bud & 6 & $15 \%$ \\
\hline & & Moderntt & 17 & $42.5 \%$ \\
\hline & & Good & 17 & $42: 5 \%$ \\
\hline
\end{tabular}

Table 4 showed that the student's liveliness during the learning process in pre-cycle was $52.5 \%$ (21 students)in bad, 25\% (10 students) in moderate, and $22.5 \%$ (9 students) in good. In Cycle I, the student's liveliness was $25 \%$ (10 students) in bad, 37.5\% (15 students) in moderate, and $37.5 \%$ (15 students) in od. In Cycle II, $12.5 \%$ (5 students) was in bad 'eliness, $42.5 \%$ (17 students) had moderate 'eliness, and45\% (18 students) was in good 'eliness. Meanwhile, in terms of learning autonomy, $\%$ (16 students) was not autonomous, 42.5\% (17 Idents) was autonomous enough, and $17.5 \%$ (7 Idents) had good learning autonomy. In Cycle I, $1 \%$ (8 students) was in bad learning autonomy, $.5 \%$ (21 students) was in moderate, and $27.5 \%$ (11 
students) was good. In Cycle II, 15\%(6students) was in bad autonomy, 42.5\% (17 students) was moderate, and $42.5 \%$ (17 students) had good autonomy. Thus, by inquiry-based learning model, both student's liveliness and learning autonomy improved well and gave great impacts to the improvement of the ability in Poem Appreciation.

\section{CONCLUSION}

The implementation of inquiry-based learning model for teaching Poem Appreciation to students of Widya Dharma-Klaten University, majoring in the Department of Indonesian Language and Art Education could improve the student's liveliness and learning autonomy. The improvement occurred in classical completion, the lowest score, the highest score, and average score from pre-cycle to Cycle II. The classical completion increased by $75 \%$ (from $17.5 \%$ to $92.5 \%$ ), while the average score improved by 16.65 (from 60.25 to 76.9 ). The improvement also happened to the lowest score by $27.5 \%$ (from 54 to 65) and the highest score by $37.5 \%$ (from 75 to 90 ). Minimum Completion Criteria could be reached by $92.5 \%$ students. Student's liveliness and learning autonomy from pre-cycle, Cycle I, and Cycle II consecutively improved significantly.

\section{REFERENCES}

[1] Aminudin. 2010. Pengantar Apresiasi Karya Sastra. Bandung: Sinar Baru Algensindo.

[2] Arikunto, Suharsimi, Suhardjono, danSupardi. 2006. PenelitianTindakanKelas. Jakarta: BumiAksara.

[3] Barman, C and Kotar. 1989. "Making it Work". Science Scope.12 (5).28-31.

[4] Benson, P. 2001. Teaching and Researaching Autonomy in Language Learning. England: Pearson Education Limited.

[5] Bruce, B.C. and Bishop.2002. "Using the Web to Support Inquiry-Based Literacy Development". Journal of Adolescent and Adult Literacy. 45(8), 706-714.

[6] Budnitz, N. 2003. What Do WeMeanby Inquiry?

http://www.biology.duke,edu/cibl/inquiry/wha tisinquiry.htmDiakses 21 Februari 2015.

[7] Crabtree, Helen. 2003. "Improving Student Learning Using an Enquiry Based Approach" in Education in a Changing Environment 17 18 September 2003. Salford: The University of Salford.

[8] Exline, J. 2004. What is Inquiry-based learning?

htpp://www.thirteen.org.edonline.concept 2 cla ss/inquiry/index.html. Diaksestanggal 21 Februari 2015.
[9] Green, Lena, Janet Condy\& Agnes Chigona. 2012. "Developing the Language of Thinking Within a Classroom Community of Inkuiri: Pre-Servis Teacher's Experiences" in South African Journal of Education.

[10] HarsonodanDjokoDwiyanto. 2005. Pembelajaran Berpusat Mahasiswa. Yogyakarta: Aditya Media bekerjasamadenganPusatPengembanganPendi dikan UGM.

[11] Hersulastuti. 2012. Model Pembelajaran Bahasa Inggris Berbasis Inkuiri untuk Sekolah Menengah Kejuruan. Surakarta: Disertasi (tidakdipublikasikan).

[12] Hyun-Hwa Lee \& Jean D. Hines. 2012. "Incorporating Active Learning and Student Inquiry into an Introductory Merchandising Class" Published by Canadian Center of Science and Education. www.ccsenet.org/hes diakses 21 Februari 2015.

[13] Joyce, Bruce, Marsha Weil, and Emily Calhoun. 2009. Models of Teaching. Eight Edition. USA: Pearson Education, Inc.

[14] Khatib, Mohammad. 2011. "A New Approach to Teaching English Poetry to EFL Students" in Journal of Language Teaching and Reseacrh, Vol. 2, No. 1 pp. 164-169 January 2011.

[15] Mulyaningsih, $\quad 2011$ PenelitianTerapan. Yogyakarta: UNY Press.

[16] National Research Council. 1996. National Science Education Standards. Washington, D.C.: National Academic Press.

[17] Sagala, Syaiful. 2010. Konsep dan Makna Pembelajaran. Bandung: Alfabeta.

[18] Sanjaya, Wina. 2006. Strategi Pembelajaran Berorientasi Standar Proses Pembelajaran. Jakarta: Kencana Prenada Media Group.

[19] Sayuti, Suminto A. 2002. Berkenalan dengan Puisi. Yogyakarta: Gama Media.

[20] ------. 1994. "Pengantar Pengajaran Puisi" dalam Pengajaran Sastra, Jabrohim (Ed.). Yogyakarta: Pustaka Pelajar.

[21] Smith, R.S. and Rebecca Walker. 2010. Can Inquiry based learning strengthen the links between teaching and disciplinary research? Journal of Studies in Higher Education. Vol. 35 No. 6 p. 723 - 740.

[22] Sukini, Andayani, Muh. Rohmadi, Budhi Setiawan. 2016. " Poem Appresciation Learning Model in Indonesia Exploration Study and Needs Analysis”. International Journal of Languages Education and 
Teaching Year 4 Volume 4 Issue 3 December 2016.

[23] Suwandi, Sarwiji.

2012.

PenelitianTindakanKelas (PTK) danPenulisanKaryaIlmiah. Cetakan Ke-2. Surakarta: Yuma Pustaka.

[23] Teeuw, A. 1988. Sastra dan Ilmu Sastra: Pengantar Teori Sastra. Cet. Ke-2. Jakarta: Pustaka Jaya.
[24] Waluyo, Herman J.2008. Pengkajian dan Apresiasi Puisi. Salaatiga: Widya Sari Press.

[25] Wells, Jill Fielding \& Katie Maker (2003). "Student (dis)engagement in Mathematics" in Department of Educations, Training and The Arts. Australia: The University of Queensland.

[26] Yin, Robert K. 2002.StudiKasusDesaindanMetode. (DiterjemahkanDjauziMudzakir). Jakarta: Raja Grafindo. 